\title{
Exceptional in vivo catabolism of neurodegeneration-related aggregates
}

\author{
Zsolt Datki ${ }^{*}$ D, Zita Olah', Tibor Hortobagyi ${ }^{2,3}$, Lilla Macsai ${ }^{1}$, Katalin Zsuga ${ }^{4}$, Livia Fulop ${ }^{5}$, Zsolt Bozso ${ }^{5}$, Bence Galik ${ }^{6}$, \\ Eva Acs $^{7,8}$, Angela Foldi ${ }^{8}$, Amanda Szarvas ${ }^{1}$ and Janos Kalman ${ }^{1}$
}

\begin{abstract}
Neurodegenerative diseases are linked to a systemic enzyme resistance of toxic aggregated molecules and their pathological consequences. This paper presents a unique phenomenon that Philodina acuticornis, a bdelloid rotifer, is able to catabolize different types of neurotoxic peptide and protein aggregates (such as beta-amyloids /Aß/, alpha-synuclein, and prion) without suffering any damage. P. acuticornis is capable of using these aggregates as an exclusive energy source (i.e., as 'food', identified in the digestive system and body) in a hermetically isolated microdrop environment, increasing their survival. As regards $A \beta 1-42$, five other bdelloid rotifer species were also found to be able to perform this phenomenon. Based on our experiments, the A 1 1-42-treated bdelloid rotifers demonstrate significantly increased survival (e.g. mean lifespan $=51 \pm 2.71$ days) compared to their untreated controls (e.g. mean lifespan $=14 \pm$ 2.29 days), with similar improvements in a variety of phenotypic characteristics. To our knowledge, no other animal species have so far been reported to have a similar capability. For all other microscopic species tested, including monogonant rotifers and non-rotifers, the treatment with $A \beta 1-42$ aggregates proved to be either toxic or simply ineffective. This paper describes and proves the existence of an unprecedented in vivo catabolic capability of neurotoxic aggregates by bdelloid rotifers, with special focus on $P$. acuticornis. Our results may provide the basis for a new preclinical perspective on therapeutic research in human neurodegenerative diseases.
\end{abstract}

Keywords: Alpha-synuclein, Bdelloid rotifer, Beta-amyloid, Catabolism, Lifespan, Prion

\section{Introduction}

Neurodegenerative disorders, such as Alzheimer's disease (AD), Parkinson's disease (PD), and prion disease, could be regarded as phenotypes secondary to the progressive functional impairment of proteomes. $[29,52,53]$. The molecular basis of aging in the brain may be described as an accelerated accumulation accompanied by a decreased clearance and degradation of misfolded proteins [46]. There is a clear correlation between protein aggregation and aged-related pathologies. The intramolecular regions arranged in $\beta$-sheet conformation are highly resistant to enzymatic degradation. [32, 51] The various neurotoxic aggregates, such as those composed of beta-amyloid $(A \beta)$, alphasynuclein $(\alpha-S y n)$, and prion (normal cellular prion protein $/ \mathrm{PrPC} /$ and pathogenic prion protein 'scrapie' /PrPSc/), share common features, with their accumulation and aggregation facilitating neurodegeneration.

\footnotetext{
* Correspondence: datki.zsolt@med.u-szeged.hu; datkizsolt@gmail.com ${ }^{1}$ Department of Psychiatry, Faculty of Medicine, University of Szeged, Kalvaria sgt. 57, Szeged H-6725, Hungary

Full list of author information is available at the end of the article
}

The peptide and protein aggregates in neurodegenerative diseases have several characteristics in common; however, their different molecular structures and pathomechanism may lead to differences in their toxicity [38]. Therefore, investigation of aggregate degradation has emerged from a marginal area of protein chemistry to become a highly relevant field in neuropharmacological science [25]. Although the pathological role of these aggregates has been well established, at present, no universal and satisfactory method exists for their in vivo degradation as a potential therapeutic tool. Misfolded peptide and protein aggregates can be partially digested by several endogenous enzymes, such as insulin-degrading enzyme (IDE) [23], neprilysin (NEP) [16], endothelinconverting enzyme [12], angiotensin-converting enzyme [14], plasmin [47] and matrix metalloproteinases [1]; however, their presence and function is apparently insufficient in a scenario that leads to neurodegenerative disorders.

Amyloids, such as $A \beta s$, are key molecules in agingassociated diseases, representing a starting point in the 
development of dementias. Therefore, their accumulation is one of the most important toxic processes during the course of cerebral $A \beta$-related pathologies, which is potentiated by a reduced clearance and insufficient degradation [30]. The understanding and modulation of $A \beta$ toxicity and its metabolism might provide novel approaches in the treatment of $A \beta$-related dementias, including $\mathrm{AD}$ and cerebral amyloid angiopathy.

Physiologically, two major enzymes are predominantly implicated in the partial degradation of $\mathrm{A} \beta \mathrm{s}$ : NEP and IDE $[6,16]$. NEP is a membrane-anchored zincdependent endopeptidase, being able to cleave both $A \beta$ monomers and oligomers. The role of NEP in the pathogenesis of $\mathrm{AD}$ is indicated by its decreased expression in the AD brain, particularly in vulnerable regions such as the hippocampus and the midtemporal gyrus, a phenomenon associated with increased $A \beta$-deposition [54]. IDE, a thiol- and zinc-dependent metallopeptidase, appears to participate in the catabolism of insulin and $\mathrm{A} \beta$ as well, and its decreased expression was reported in the hippocampus of AD patients [55]. Although IDE mediates these processes in vivo, it still remains a question how this cytoplasmic protein can degrade extracellular $A \beta$ aggregates in the brain. Further relevant membrane proteases involved in $A \beta$ degradation include plasmin, cathepsin $B$, endothelin-converting enzyme, and certain members of matrix metalloproteinase family, which are highly tissue- and brain region-specific [2]. Potential therapeutic approaches to reduce the accumulation of harmful neurotoxic proteins include the facilitation of anti-aggregation processes or the enhancement of their clearance. As an example, $\beta$-sheet breakers bind to the central hydrophobic core of $A \beta 1-42$ and attenuate the formation of the $\beta$-sheet structures. These molecules could destabilize the senile plaques; however, they do not provide adequate solution to the degradation and catabolism of overexpressed toxic aggregates. [40] Therefore, an ideal protective strategy against aggregateinduced neuronal damage requires more complex and practical solutions, with dual mechanisms of action targeting both the destabilization and degradation of toxic aggregates.

Treatments with different exogenous $A \beta$ isoforms are widely used models of $\mathrm{AD}$ and earlier studies used various in vitro and in vivo systems to reveal their exact effects. Several studies were performed on human neuroblastoma cells $[7,36]$, invertebrates, rodents, and primates [13, 20, 42]; however, only a single publication aimed at describing the effects of $\mathrm{A} \beta$ on bdelloid rotifers, e.g. Philodina species [36]. This unique study by Poeggeler et al. [36] reported the treatment of rotifers with $A \beta 1-42$ in order to test the efficacy of an antioxidant molecule (LPBNAH) against the supposed neurotoxicity of the peptide aggregates. In their in vivo studies with rotifers, the authors applied doxorubicin instead of $A \beta 1-42$, because this toxin gave more consistent results in rotifers. In fact, the neurotoxic effect of $A \beta 1-42$ in this model could not be proven. Our aim was to investigate this intriguing phenomenon that was only slightly touched upon in the paper of Poeggeler.

Bdelloid rotifers, as microinvertebrates, are one of the most commonly used animal models in toxicity-, aging-, and longevity-related research. These organisms are multicellular animals with well-defined anatomical characteristics, possessing a ciliated head structure, bilateral ovaries, mastax, ganglia, muscles, digestive, nervous, and secretory systems, and photosensitive, and tactile organs. $[5,15]$. Due to their peculiar anatomy and physiology, these animals have outstanding advantages in terms of culturing and are rather easy to work with [44]. Rotifers are extremely resistant to environmental alterations and successfully adapt to the different types and amounts of nutrients present in their natural habitat. The natural decomposition of organic materials is a process that results in the formation of precipitates and aggregates, which represent potential nutrients for rotifers [50]. The metabolic utilization of all these available organic material resources is their special property [4].

In a prior publication, we reported the development of a unique and straightforward method [34], which enables the investigation of the effect of several different agents or impacts on various phenotypic parameters of microinvertebrates. The oil-covered microdrop technology, adopted from human in vitro fertilization, is a well-controllable construction to assess the lifespan and other features of a single isolated animal (one-housed rotifer).

In our present study, we examined the effect of various neurodegeneration-related peptide and protein aggregates under complete dietary restriction, ensuring that the individual rotifers had no other organic source to be used for gluconeogenesis. Observing an intriguing increase in survival upon treatment with aggregates, as a next step, we investigated different types of microentities in neurotoxic aggregate-supplemented environment. To our knowledge, this study is the first to address the in vivo catabolism of these molecules as dietary sources in microscopic animals such as rotifers. Our findings may provide a starting point to understand the possible ways of degradation of abnormally folded neurotoxins despite their aggregated state and consequent protease resistance, a subject with high potential relevance in the treatment of neurodegenerative proteinopathies.

\section{Materials and methods Materials}

The $A \beta 1-42, A \beta 1-42$ [Gln22], $A \beta 1-40, A \beta 25-35$, two scrambled isoforms (A $\beta 1-42$ S1: LKAFDIGVEYNKVGEGFAISHGVAHLDVSMFGEIGRVDVHQA and A $\beta 1-42$ S2: 
KVKGLIDGAHIGDLVYEFMDSNSAIFREGVGAGHVHV AQVEF) were prepared in the Department of Medical Chemistry, University of Szeged, Szeged, Hungary. The peptides were synthesized on an Fmoc-Ala-Wang resin using $\mathrm{N} \alpha$-Fmoc-protected amino acids with a CEM Liberty microwave peptide synthesizer (Matthews, NC, USA). The peptide A $\mathrm{B} 11-42$ (H-7668.1000) was purchased from Bachem (Torrance, CA, USA), whereas A $\beta 1-28$ (A0184) and $\alpha$-Syn (type E46K human; S4447) were purchased from Sigma-Aldrich (St. Louis, MO, USA). The mature part (25244) of recombinant bovine prion protein (PrPC, AG210) was obtained from Merck Millipore (Darmstadt, Germany). EZ4U (BI-5000; Biomedica Medizinprodukte, Wien, Austria) and Calcein-AM (17,783; Sigma-Aldrich) cell viability assays were used to measure the toxicity of the aggregates. For in vivo and in vitro investigations of the different aggregates, we applied Bis-ANS (4,4' -dianilino-1,1'binaphthyl-5,5'-disulfonic acid dipotassium salt; D4162) and Congo red (CR; C6277) dyes obtained from SigmaAldrich. To detect gold-tagged beta-amyloid (Au-A $\beta 1-42$ ) in $P$. acuticornis with scanning electron microscopy (SEM), we used Gold(III) chloride (AuCl3 x 2 $\mathrm{H}_{2} \mathrm{O}$; 01216, Reanal, Budapest, Hungary) and A $\beta 1-42$ aggregates. Distilled water (DW) was prepared in our laboratory (Millipore-type, ultrapure, demineralized DW).

\section{Preparation of aggregating peptides and proteins}

The synthesis and characterization of the $A \beta$ peptides were conducted as previously described by Bozso et al. [3] with minor modifications: the concentrations of the stock solutions were $1 \mathrm{mg} / \mathrm{mL}(\mathrm{DW})$; the aggregation time was $3 \mathrm{~h}$ or 3 days $\left(25{ }^{\circ} \mathrm{C}, \mathrm{pH} 3.5\right)$; the neutralization (to $\mathrm{pH} 7.5$ ) was performed with $\mathrm{NaOH}$ $(1 \mathrm{~N})$ [17]; after 10-fold dilution with standard medium, the final (working) concentrations were $100 \mu \mathrm{g} / \mathrm{mL}$. The amount of diluted cations and anions in standard medium $(\mathrm{mg} / \mathrm{L}): \mathrm{Ca}^{2+} 31.05 ; \mathrm{Mg}^{2+} 17.6$; $\mathrm{Na}^{+} 0.9 ; \mathrm{K}^{+} 0.25 ; \mathrm{Fe}^{2+} 0.001 ; \mathrm{HCO}_{3}^{-} 153.097 ; \mathrm{SO}_{4}^{-} 3 ; \mathrm{Cl}$ 0.8; $\mathrm{F}^{-} 0.02 ; \mathrm{H}_{2} \mathrm{SiO}_{3} 3.3(\mathrm{pH}=7.5)$ [41]. To prepare the PrPSc form of PrPC, the stock solution of PrPC was aggregated for $24 \mathrm{~h}$ at $\mathrm{pH} 2[49,57]$. The $\mathrm{pH}$ of the prepared prion was also adjusted to $\mathrm{pH} 7.5$ before being used to treat the rotifers.

\section{Collection, isolation, identification and harvesting of different animal species}

To collect and isolate different microscopic species, we used the method described by Debortoli et al. [9] with minor modifications. The sampling sites were distributed within two areas of about $500 \mathrm{~m}^{2}$ near Szeged (Southern Great Plain, Hungary) and Saint-George (Transylvania, Romania). Fifty patches of highly hydrated moss (with minimal soil) were collected from the northern side of trees (of the genera Acer and Platanus) and from their close environment. Briefly, the collected samples were hydrated with the standard medium in separate flasks. After identifying the species by using methods described in the literature $[18,21,24,33,48]$ we applied speciesspecific information (e.g., body size in relation to age) to collect relatively young (approximately $3-5$ days old) and individuals of the same size. The isolation protocol from the samples was in line with the method of Debortoli et al. [9]. However, instead of culturing; we collected and isolated these animals (using micropipette) to create monoclonal populations. After washing these groups with standard medium, we harvested as many individuals as needed $(n=30)$ for the experiments. The species collected in Hungary comprised Philodina vorax Janson, 1893; Philodina megalotrocha Ehrenberg, 1832; Lepadella patella Müller, 1773; Lecane arcula Harring, 1914; Lecane agilis Bryce, 1892; Lecane hamata Stokes, 1896; Lecane closterocerca Schmarda, 1859; Brachionus diversicornis Daday, 1883; Brachionus calyciflorus calyciflorus Pallas, 1766; Brachionus forficula Wierzejski, 1891; Caenorhabditis elegans Maupas, 1900; Typhloplana viridata Abildgaard, 1789; Vorticella convallaria Linnaeus, 1758; Stylonychia mytilus Müller, 1773. The species collected in Romania comprised Mniobia russeola Zelinka, 1891; Adineta steineri Bartô̂, 1951; Habrotrocha elusa Milne, 1916; Filinia terminalis Plate, 1886; Lindia torulosa Dujardin, 1841; Hypsibius dujardini Doyère, 1840; Centropyxis aculeata Ehrenberg, 1832. Processes related to culturing and harvesting Philodina acuticornis Murray, 1906 were performed (in artificial environment) as previously described by our group [34]. The animals were photographed (Nikon D5500, Nikon Corp., Kanagawa, Japan) under the light microscope (at 200x magnification; Leitz Labovert FS, Wetzlar, Germany) by taking serial images at every $5-\mu \mathrm{m}$ intervals, yielding a total of 20-30 photographic layers per animal, which were subsequently merged into one superimposed picture (by using Photoshop CC software, Adobe Systems Inc., San Jose, CA, USA) to achieve better resolution.

\section{In vitro and in vivo treatment and monitoring}

To test the previously described neurotoxic effects of the examined aggregates in vitro, we used a differentiated $\mathrm{SH}$ SY5Y human neuroblastoma cell line (Sigma-Aldrich), with the related culturing and differentiating methods based completely on our previous works [7, 26]. Five-dayold animals (as determined by BSI) were chosen for the experiments, an age that precedes the beginning of the reproductive stage (i.e., egg production) by 2 days. Before treatment (using micropipette) of individual rotifers with aggregated molecules $(0.1,10$ and $100 \mu \mathrm{g} / \mathrm{mL})$, the stock solutions $(1 \mathrm{mg} / \mathrm{mL})$ were ultrasonicated (Emmi-40 HC, EMAG AG, Mörfelden-Walldorf, Germany) for $10 \mathrm{~min}$ at $45 \mathrm{kHz}$ to achieve sterilization and homogenization. 
During the in vivo experiments, the viability assay, the assessments of descriptive characteristics (such as normalized mean lifespan /NML/, body size index /BSI/, bright light disturbance /BLD/, mastax contraction frequency $/ \mathrm{MCF} /$, and cellular reduction capacity / $\mathrm{CRC} /$ ), and the assembly of the experimental setup (with the oil-covered microdrop) were carried out as presented in detail previously [34].

\section{Detections of exo- and endogenic $A \beta 1-42$ in $P$. acuticornis}

Optical analysis in live rotifers (Fig. 1a-d): The juvenile (5 days old) animals were identified on the basis of their body size as read from a calibration curve previously described [34]. For the treatment (in 96-well plate; 3695, Costar, Corning Inc., USA) of preselected and 1-day starved rotifers, we used unlabelled A $\beta 1-42$ (3 h and 3 days aggregated) as 'food' source. After 12 days the content of the wells were changed to labelled A $\beta 1-42$, aggregated for $3 \mathrm{~h}$ (in vitro marked with $10 \mu \mathrm{M}$ Bis-ANS fluorescent dye for $30 \mathrm{~min}$ ) or 3 days (in vitro marked with $50 \mu \mathrm{M} \mathrm{CR}$ dye for $1 \mathrm{~h}$ ). Applying $5 \mathrm{~h}$ treatment ('feeding'), we detected the optical signals (at 200x magnification) in the digestive system (stomach and intestine) of individual rotifers by an optical/fluorescence microscope (Olympus IX71, OLYMPUS, Budapest, Hungary). The representative images demonstrate the localization of $A \beta 1-42$ in the body of rotifers compared to untreated, normally fed $(600 \mu \mathrm{g} / \mathrm{mL}$ yeast suspension $)$ and unfed (starved) controls (Fig. 1a-d). Unfed individuals labelled with these two dyes (control background without $A \beta 1-42$ treatment) have no signal (photo not shown).

Searching for endogenous $A \beta 1-42$ in rotifers: The immunological detection of the presence or absence of natural $\mathrm{A} \beta 1-42$ in $P$. acuticornis species has a central role in interpreting the relations of $A \beta 1-42$ and rotifers. After harvesting, the animals were put into $-75{ }^{\circ} \mathrm{C}$ for $30 \mathrm{~min}$ in standard medium. The number of rotifers were $10^{4}$ per sample. The thawed animals were ultrasonicated (at $45 \mathrm{kHz}$ at room temperature for $10 \mathrm{~min}$ ). The rotifer homogenate was centrifuged $(300 \mathrm{x} g$ for $5 \mathrm{~min}$ at $24^{\circ} \mathrm{C}$ ) to eliminate the exoskeletons of the dead animals. The protein concentration of the supernatant was determined by the Qubit Protein Assay Kit (Q33212; Thermo Fisher Scientific, Wilmington, DE, USA) following the manufacturer's protocol. The concentration of the stock suspension was $340.54 \mu \mathrm{g} / \mathrm{mL}$, which was diluted to the final protein concentrations $(\mu \mathrm{g} / \mathrm{mL})$ of $20,15,10,5$ and 1 in standard medium. Commercially available A $\beta 1-42$-specific sandwich ELISA kits (Innotest A $\beta 1-42,81,576$, Fujirebio, Gent, Belgium) were used according to the manufacturer's protocol for the quantitative detection of $A \beta 1-42$ in the diluted rotifer homogenate.

The Au-Aß1-42 complex detection with SEM (Fig. 1f, $\mathrm{g})$ : The stock solutions of $\mathrm{A} \beta 1-42(1 \mathrm{mg} / \mathrm{mL})$ and $\mathrm{AuCl}_{3}$ $(2.8 \mathrm{mg} / \mathrm{mL})$ were prepared with $\mathrm{DW}$. The 3-dayaggregated $A \beta 1-42$ solution was mixed for $2 \mathrm{~h}$ with the $\mathrm{AuCl}_{3}$ solution in a $1: 4 \mathrm{M}$ ratio, according to the number of Au-binding sites of monomeric A $31-42$ (one methionine and three histidine residues). To remove excess $\mathrm{Au}$ ions, two rounds of centrifugation (25,000 x g for $10 \mathrm{~min}$ at $24{ }^{\circ} \mathrm{C}$ ) with supernatant replacement were used. $\mathrm{NaOH}(1 \mathrm{~N})$ was applied to adjust the $\mathrm{pH}$ to 7.5 . Peptide content of the final pellet was determined by the Qubit $^{\text {TM }}$ Protein Assay Kit (Thermo Fisher Scientific). The middle-aged (15 days old) harvested rotifers were starved (i.e., complete food deprivation) for 2 days. After washing the rotifers in 6-well plates (containing $10^{4}$ adherent animals per well), each well was treated with $\mathrm{Au}-\mathrm{A} \beta 1-42$ complex in a dose of $100 \mu \mathrm{g} / \mathrm{mL}$ for 1 day. The wells were decanted and washed twice with standard medium and after an incubation period of $6 \mathrm{~h}$ (the time to empty the digestive tract of the animals), the wells were washed again and the populations were fixed and dehydrated with $96 \% \mathrm{EtOH}$ at $-75{ }^{\circ} \mathrm{C}$ for $5 \mathrm{~min}$, followed by a partial rehydration with $30 \% \mathrm{EtOH}$ at room temperature for $30 \mathrm{~min}$. After fixation with $1 \%$ paraformaldehyde (for $30 \mathrm{~min}$ ), the wells were washed twice with DW. The collected animals were transferred with pipette to the centre of a round glass coverslip (diameter: $12 \mathrm{~mm}$, thickness: $0.15 \mathrm{~mm}$; 89,167-106, VWR International, Houston, TX, USA), and were allowed to dry. The samples were not coated with gold. The structural integrity of the rotifer bodies was controlled with digitally recorded photographs (Nikon D5500). The selected bodies (based on their quality) were subjected to SEM (Zeiss EVO MA 10, Carl Zeiss, Oberkochen, Germany) [2]. The sample-carrier coverslip was fixed onto a stub using a double-sided carbon tape. The fine structure of the rotifers was observed and photo-documented with the SEM (Fig. 1f, g), operating at $10 \mathrm{kV}$ with an $8-\mathrm{mm}$ working distance, using a backscattered electron detector in variable pressure mode at $30 \mathrm{~Pa}$. The white balance of SEM photographs was normalized.

\section{Congo red aggregation assay}

The methods described by Klunk et al. [19] and Datki et al. [8] were used for these experiments. The preparation and aggregation of the peptides and proteins for the CR assay was the same as described in the in vitro and in vivo treatment protocols. A volume of $10 \mu \mathrm{L} C R$ stock solution $(0.5 \mathrm{mM})$ was added to each aggregate-containing tube $(490 \mu \mathrm{L}$; $100 \mu \mathrm{g} / \mathrm{mL}$ ) and these mixtures were incubated for 

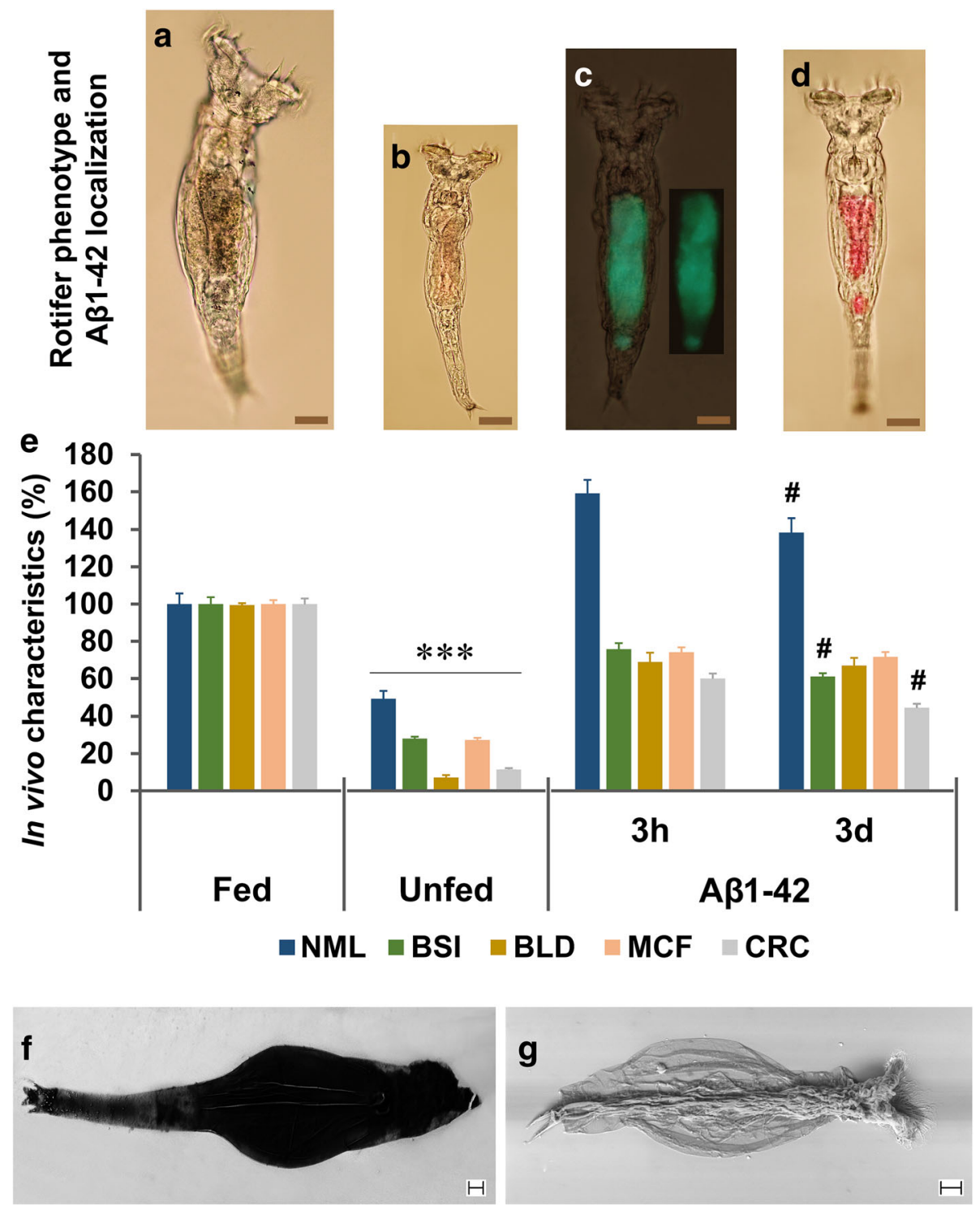

Fig. 1 Localization and demonstration of the beneficial effects of aggregated A $A 1-42$ on $P$. acuticornis. Juvenile rotifers were selected in different groups after 1-day starvation: fed (a; 12 days normal feeding), unfed (b; 12 days starvation) and A $1-42$ treated (for 12 days). The Aß1-42 in the digestive system (stomach and intestine) of live rotifers were visualized by fluorescent Bis-ANS (c; green colour in the representative photograph; $3 \mathrm{~h}=$ aggregated for $3 \mathrm{~h}$ ) and absorbent Congo red ( $\mathbf{d}$; red colour in the representative photograph; $3 \mathrm{~d}$ = aggregated for 3 days). Untreated individuals labelled with these two dyes showed no signal (not shown). e The normalized mean lifespan (NML) of the AB1-42-treated animals was significantly longer than that of their normally fed and unfed untreated controls, with a significant difference between the $3 \mathrm{~h}$ - and $3 \mathrm{~d}$-aggregated forms. Besides NML, four viability markers were measured, including body size index (BSI), bright light disturbance (BLD), mastax contraction frequency (MCF), and cellular reduction capacity (CRC). The AB1-42-treated rotifers performed significantly better than their unfed untreated controls and there were significant differences between the subgroups treated with two the differently aggregated forms in BSI and CRC. The concentration of Aß1-42 was $100 \mu \mathrm{g} / \mathrm{mL} ; n=30$ (NML), 50 (BSI), 20 (BLD), and 24 (MCF) one-housed individual rotifers per group; $n=24$, well with normalized absorbance to rotifer number (CRC). The scale bars in the proportional representative photographs represent $20 \mu \mathrm{m}$ (*, significant difference from the fed and Aß1-42-treated groups; \#, significant difference from the group treated with the $3 \mathrm{~h}$ aggregated form). The possible distribution of the exogenous Au-AB1-42 complex was studied in vivo with SEM in the body of $P$. acuticornis: $\mathbf{f}$ rotifer without treatment (background); $\mathbf{g}$ Au-Aß1-42-treated rotifer. Homogenously signals of gold can be detected in Au-Aß1-42-treated entities. Scale bar represents $10 \mu \mathrm{m}$

$20 \mathrm{~min}$ at room temperature and shaken every $5 \mathrm{~min}$ (at $50 \mathrm{rpm}$ for $10 \mathrm{~s}$ ), followed by centrifugation at $25,000 \times \mathrm{g}$ for $15 \mathrm{~min}$. The supernatant was carefully removed with a pipette and the sediment (pellet) was resuspended in standard medium $(0.5 \mathrm{~mL})$. The aggregate-bound CR content of the suspensions was measured spectrophotometrically at $540 \mathrm{~nm}$ with a BMG NOVOStar plate reader (BMG Labtech, Ortenberg, Germany), using a 96-well plate (Costar). 


\section{Statistics}

The error bars represent the standard error of the mean (S.E.M.). For comparative statistical analysis, the one-way ANOVA was used followed by the Bonferroni post hoc test with SPSS 23.0 software for Windows. A $p \leq 0.05$ was regarded as statistically significant, with the different levels of significance indicated as follows: $\mathrm{p}^{\#} \leq 0.05, \mathrm{p}^{* * *} \leq 0.01$ and $\mathrm{p}^{* * *} \leq 0.001$. Kaplan-Meier curves were applied to present the survival of the groups. The GraphPad Prism 7.0b software (GraphPad Software Inc., La Jolla, CA, USA) was used for the illustration and statistical analysis (log-rank; Mantel-Cox) of survival.

\section{Results}

To investigate the background of less 'consistent results' with A $\beta 1-42$ toxicity in bdelloid rotifers reported by Poeggeler et al. [36], we investigated the effect of different neurodegeneration-related protein aggregates on one-housed $P$. acuticornis in an experimental setup [34] inspired by that applied human in vitro fertilization (i.e., oil-covered microdrop). This assay system allows the observation of our model organisms at an individual level. First, we examined the effect of A $\beta 1-42$, which we predicted to be toxic to $P$. acuticornis. Surprisingly; however, treatment of the animals with $A \beta 1-42$ resulted in a significantly longer mean lifespan ( $51 \pm 2.71$ days) than in the case of unfed $(14 \pm 2.29$ days $)$ and normally fed (32 \pm 2.72 days) controls. To localize and demonstrate the presence of $A \beta 1-42$ aggregates in the body of the rotifers, we used $\beta$-sheet-specific fluorescent and absorbent dyes. Animals in the representative photographs (Fig. 1a-d) are shown in proportional sizes and display the strong differences between the groups. The Fig. 1c, $d$ show the presence of the exogenous $A \beta 1-42$ in the digestive system of the rotifers after 'feeding' ad libitum (above is the stomach and below is the intestine). To characterize the A $\beta 1-42$-treated $P$. acuticornis animals, we applied some previously published [34] experimental monitoring assays. The results (Fig. 1e) are evidences to the fact that this bdelloid rotifer can use the A $\beta 1-42$ as food in isolated environment without the presence of any other organic material. The NML of groups treated with either $3 \mathrm{~h}$ or 3 days aggregated $A \beta 1-42$ significantly increased compared to unfed (starved) controls. The BSI and the BLD indicated phenotypical and physiological changes of the treated animals. These characteristics were increased by $40 \%$ and $60 \%$ compared to untreated starved controls, respectively. The MCF and the CRC suggested intensified energy level as represented by neuromuscular and cellularredox activities. These two markers were increased by $46 \%$ and $42 \%$ compared to unfed entities, correspondingly. The A $\beta 1-42$-treated one-housed rotifer individuals performed much better in the measured parameters than their unfed controls, and they do not drastically differ from the normally fed counterparts. These results suggest that $\mathrm{A} \beta 1-42$ is not toxic to $P$. acuticornis and it could be used by them as an exclusive dietary source to live and develop in an hermeticallyisolated environment. As the next step, we aimed at detecting the possible presence of endogenous $A \beta 1-42$ in $P$. acuticornis species. We applied ELISA for the quantitative analysis of $\mathrm{A} \beta 1-42$ in the rotifer homogenates. Interestingly, our findings indicate that endogenous A $\beta 1-42$ is practically absent in P. acuticornis species, an observation first reported in the literature. To localize exogenous $A \beta 1-42$ aggregates in the live (Fig. 1a) rotifers (beyond the digestive system) we applied Au-tagged A 1 1-42 aggregates, detected with SEM (Fig. 1f, g). After fixating and drying the Au-A $11-42$-treated and untreated animals, we monitored the possible distribution of the remnants of the potentially catabolized peptide. We found that in Au-A $31-42$-treated animals, the signal of gold-ions could be found homogeneously everywhere in their body in contrast to the untreated ones. The only possible source of gold in the samples was the $\mathrm{Au}-\mathrm{A} \beta 1-$ 42 complex taken up during life, as no aspecific gold coating was applied. These SEM photos are only representative.

In our study, we used eleven different peptides and proteins, with some of them being accepted as neurotoxic aggregates in neurodegenerative diseases (Fig. 2). To test and confirm the toxic effect of these aggregated peptides/proteins, we used a differentiated SH-SY5Y human neuroblastoma cell model, based on our previous works $[7,8]$. The CRC-specific EZ4U and cytoplasmic enzyme activity-sensitive Calcein-AM assays were used to test the potential effect of the various aggregates. The time-dependent differences between the respective aggregate solutions incubated for $3 \mathrm{~h}$ and 3 days were measured with CR spectrophotometric assay $[8,19]$. The data demonstrated an inverse correlation between CRbinding property and cellular toxicity of aggregates. The $\mathrm{A} \beta 1-28$, the scrambled isoforms $\mathrm{A} \beta 1-42 \mathrm{~S} 1$ and $\mathrm{S} 2$, and PrPC demonstrated low affinity to $C R$ and were not toxic to SH-SY5Y cells, accordingly.

In our next experiment, we examined whether the $P$. acuticornis is capable of catabolizing other neurotoxic aggregates as well (Fig. 3). To investigate the dosedependency of the effect of A $\beta 1-42$ on rotifers, we used three different treatment concentrations $(0.1,10$, and $100 \mu \mathrm{g} / \mathrm{mL}$ ), comparing the results with those of groups treated with equivalent concentrations of bovine serum albumin (BSA). Interestingly, we observed the highest median survival in the case of $100 \mu \mathrm{g} / \mathrm{mL} \mathrm{A} \beta 1-42$ treatment (Fig. 3a). We found that almost all $A \beta$ peptide forms tested (A $\beta 1-42, A \beta 1-42$ [Gln22], $A \beta 1-40, A \beta 11-$ 42, $A \beta 1-28, A \beta 1-42 \mathrm{~S} 1 ; A \beta 1-42 \mathrm{~S} 2$ ) were favourable 


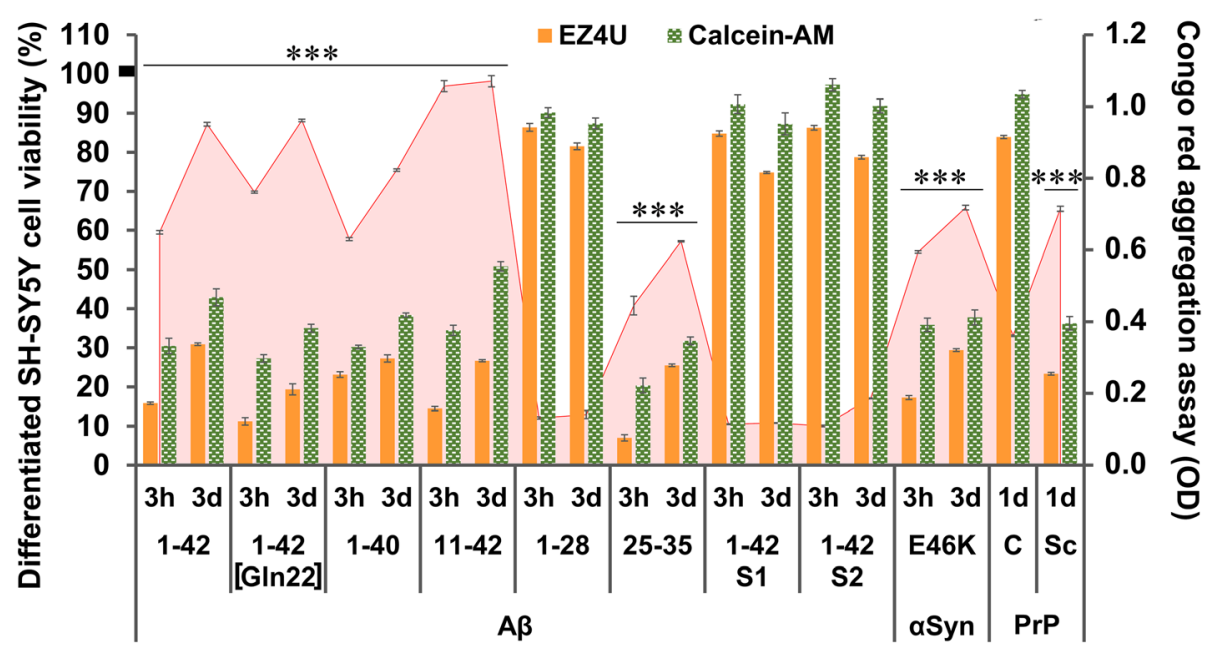

Fig. 2 Aggregation-dependent neurotoxicity of different neurodegeneration-related peptides and proteins in cell culture. To test the previously described $[10,11]$ toxic effect of neurodegeneration-related aggregates, we used a differentiated SH-SY5Y human neuroblastoma cell model. The EZ4U and Calcein-AM cell viability assays were used to detect the NADH- and esterase-activity-dependent cell viability of the cultures (presented in orange and green columns of the chart, respectively). The mean viability of the untreated control wells was regarded as 100\% (the S.E.M. of the mean was $\pm 2.8 \%$ ). The aggregation level of the proteins was measured with Congo red spectrophotometric assay (red line in the background of the chart). The length of incubation and aggregation time ( $3 \mathrm{~h}=3 \mathrm{~h}$ and $3 \mathrm{~d}=3$ days) influenced the toxicity of the treatment in most of the peptides and proteins tested. Significant differences ( $p \leq 0.01$ ) were detected between the $3 \mathrm{~h}$ - and $3 \mathrm{~d}$-groups (no markers on columns) in both viability assays. Significant differences could be detected between the $3 \mathrm{~h}$ - and $3 \mathrm{~d}$-aggregated forms in the Congo red assay for all $A \beta s$, except for AB11-42, AB1-28, AB1-42 S1, and Aß1-42 S2. Alpha-synuclein (a-Syn, type E46K) and prepared 'scrapie' (PrPSc) form of prion protein also showed significant in vitro toxicity, contrasting with the ineffective normal cellular prion (PrPC). The aggregation time of the prions was 1 day (1d). Each molecule was used in $100 \mu \mathrm{g} / \mathrm{mL}$ concentration; $n=8$ (for EZ4U and Calcein-AM) and 20 (for Congo red) wells per group. The error bars present the S.E.M. For statistical analysis, one-way ANOVA was used followed by the Bonferroni post hoc test, and the level of significance were $p^{* * *} \leq 0.001{ }^{*}$ - the significant rate of deviation from the non-toxic and non-aggregated forms /A $1-28,1-42 \mathrm{S1}, 1-42 \mathrm{~S} 2$, PrPC/ in both viability and Congo red assays)

nutrient sources, contrasting with $\mathrm{A} \beta 25-35$, which proved to be toxic to the rotifers (Fig. 3 b-c). This 'short' type of $\mathrm{A} \beta$ has a relatively low molecular weight (1060.27 $\mathrm{g} / \mathrm{mol})$ compared to the longer $\mathrm{A} \beta$ peptides (e.g., $A \beta 1-42)$, resulting in higher molar concentration $(94.3 \mu \mathrm{M})$ in a $100-\mu \mathrm{g} / \mathrm{mL}$ dose. We tested this artificial $\mathrm{A} \beta$ aggregate in a dose of $10 \mu \mathrm{g} / \mathrm{mL}$ as well, and we found it also significantly toxic (NML $58 \pm 5.8 \%$; $p \leq$ 0.01 ) when analysing the survival of the treated group compared to that of unfed controls. In addition to various $A \beta$ isoforms, $P$. acuticornis was also able to catabolize one of the most aggregation-prone forms of $\alpha$-Syn (type E46K) as well as the physiological (PrPC) and pathological forms (PrPSc) of prion protein (Fig. 3d). The Kaplan-Meier survival curves demonstrate significant differences in all treatment groups compared to the respective untreated control curve (Fig. 3a).

To investigate the universal capability of one-housed microscopic entities to catabolise A $\beta 1-42$ (aggregated for $3 \mathrm{~h}$ before treatment; Fig. 4), we examined 22 species with different phylogenetic backgrounds. These species included bdelloid rotifers: $P$. acuticornis, $P$. vorax, $P$. megalotrocha, M. russeola, A. steineri, H. elusa; monogonant rotifers: L. patella, L. arcula, L. agilis, L. hamate, $L$. closterocerca, B. diversicornis, B. calyciflorus calyciflorus, B. forficula, F. terminalis, L. torulosa; non-Rotifers: C. elegans, $H$. dujardini, T. viridata, V. convallaria, C. aculeate, S. mytilus. In order to provide adequate basis for comparison, we used an NML where the mean lifespan of the unfed (starved) control group within the respective species were regarded as $100 \%$ (contrasting with the comparisons in Fig. 1 where 100\% was the mean lifespan of the normally-fed group). From the all examined species, bdelloids (Fig. 4a-f) were the only ones that demonstrated significantly longer NMLs (240-290\%) compared to their unfed (starved) controls (100\%). As regards other species, A $\beta 1-42$ was either toxic (Fig. 4g-o of monogonants and Fig. 4s-v of non-rotifers) or had no effect (Fig. 4p-r of both groups).

The results strongly suggest that $P$. acuticornis can catabolize various form of toxic and non-toxic $A \beta s$, $\alpha$-Syn, and prion aggregates and that the investigated bdelloid rotifer species are also able to use the neurotoxic $A \beta 1-42$ aggregates as nutrients (ad libitum). This agent is either toxic or has no effect on the lifespan of other microinvertebrates examined, suggesting that the catabolism of aggregates with proteinopathy is an exceptional property of bdelloid rotifers (Fig. 5). 


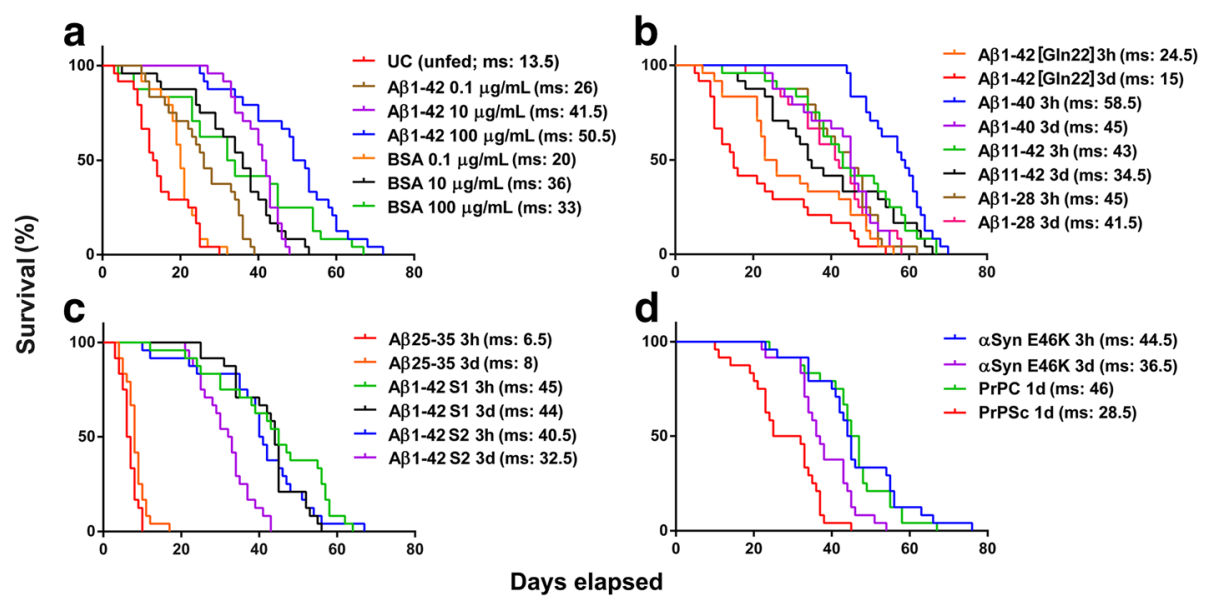

Fig. 3 The effect of different neurodegeneration-related aggregates on the survival of $P$. acuticornis. The Kaplan-Meier curves demonstrate the survival of rotifers ( $n=24$ one-housed individuals per sample type; aggregation time: $3 \mathrm{~h}=3 \mathrm{~h}$ and $3 \mathrm{~d}=3$ days). a Dose dependency: the effect of 3 h-aggregated $A B 1-42$ and BSA were tested in three different concentrations. This neurotoxic peptide as well as the nontoxic protein served as nutriments to rotifers. The survival was dose-dependent $(0.1,10$, and $100 \mu \mathrm{g} / \mathrm{mL})$ and was significantly higher in both type of treatments compared to the untreated control group (UC; $p<0.001$; log-rank test). $\mathbf{b}$ Natural $A \beta$ isoforms: we tested four natural variants of the $A \beta$ peptide (1-42 [Gln22], 1-40, 11-42 and 1-28) on rotifers in two different aggregated forms ( $3 \mathrm{~h}$ and $3 \mathrm{~d})$. All types of natural $A \beta s$ had a positive effect on the survival of the treated rotifers compared to the $U C$ (a). c Artificial A $\beta$ isoforms: the rotifers were able to use both scrambled forms of A $A 1-42$ (S1 and S2) as nutrients. As a unique exception in the series, $A \beta 25-35$ was toxic to the rotifers, decreasing their survival as compared to the UC (a). All three types of artificial A 3 s were measured in $3 \mathrm{~h}$ - and $3 \mathrm{~d}$-aggregated forms. $\mathbf{d}$ Non-A proteins: the animals treated with alpha-synuclein (a-Syn, type E46K; in $3 \mathrm{~h}$ - and $3 \mathrm{~d}$-aggregated forms) and the cellular (PrPC) or 'scrapie' (PrPSc) forms of prion protein ( $1 \mathrm{~d}=$ aggregated for 1 day) also showed a significantly longer lifespan compared to the UC (a). Each protein was used in $100 \mu \mathrm{g} / \mathrm{mL}$ concentration. The significance of log-rank (Mantel-Cox) test was $p<0.0001$ in the statistical analyses in panels $\mathbf{b}$-d. Median survival (ms) values in days are presented in the graphs. The statistical analysis of survival was performed by GraphPad Prism 7.0b

\section{Discussion}

The formation and accumulation of aggregated proteins is a central feature of several neurodegenerative diseases. The age-related dyshomeostasis promotes the aggregation of misfolded proteins. Neurodegeneration is associated with the resistance of various aggregated peptides and proteins to enzymatic degradation [39]. In transmissible spongiform encephalopathies, the endogenous PrPC, composed of the pure protein without any presence of nucleic acid components, is converted to the pathogenic and infectious form (PrPSc) [37]. The $\alpha$-Syn is a presynaptic neuronal protein, which contributes to the pathogenesis of $\mathrm{PD}$ via its toxic aggregation [35]. A $\beta$ peptides can accumulate as senile plaques, which are regarded as one of the hallmark alterations in $\mathrm{AD}[2,43]$.

Although the degradation of these amino acidcontaining organic macromolecules has been in the focus of neuropharmaceutical science for decades, there have been no proper treatments developed or methods identified for the elimination of these toxic aggregates from living systems to date. Moreover, only a fraction of these peptides and proteins can be efficiently digested by proteolytic enzymes either in vitro or in vivo. [22]
In our study, we are the first to describe the existence of the in vivo catabolism of neurotoxic aggregates by bdelloid rotifers (e.g., Philodina acuticornis), as these microinvertebrates are capable of using even neurotoxic aggregates as exclusive energy and organic material sources, prolonging their lifespan. The one-housed and aggregated A $31-42$-treated [3] P. acuticornis individuals have significantly longer lifespan and better viability compared to their untreated controls under complete dietary restriction in a fully isolated environment. This capability to improve (NML) or maintain (BSI, BLD, MCF and CRC) viability showed a correlation with the aggregation state (i.e., $C R$ affinity) of $A \beta 1-42$. The administered exogenous peptide aggregates were first localized and distributed within the digestive system of the rotifers, providing evidence of being consumed (Fig. 1). First in the literature, we demonstrated that this species have no detectable endogenous $\mathrm{A} \beta 1-42$ production. Since the treated $P$. acuticornis maintained its wellbeing, function, and redox capacity, we presume that these aggregates may serve as an obligatory energy source for gluconeogenesis in these experimental conditions. Prolonged starvation of animals causes significant physiological changes supplying glucose from amino 


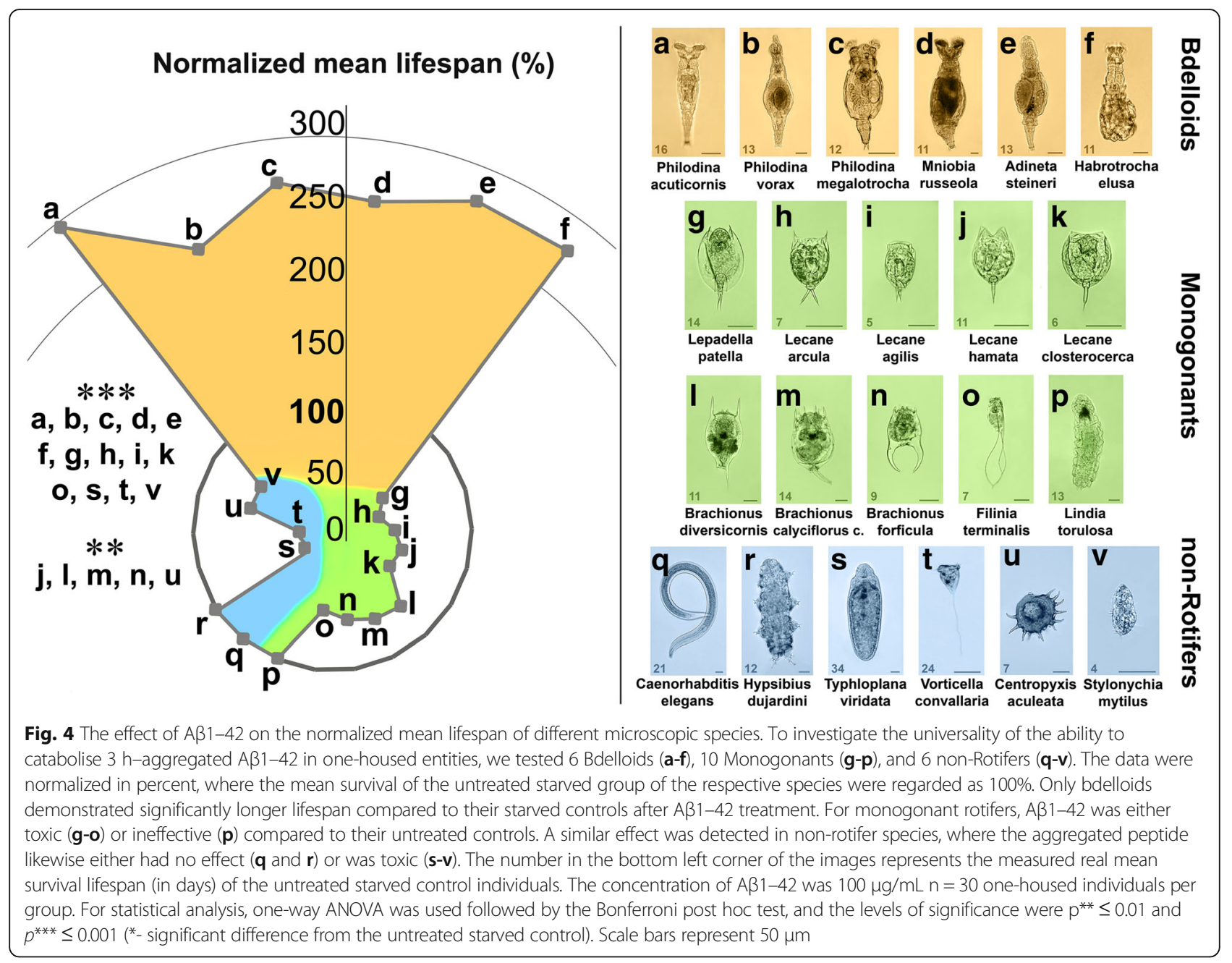

acids by metabolism, including ketogenesis and gluconeogenesis. The main function of gluconeogenesis is to maintain the glucose level via its endogenous de novo production from non-carbohydrate substrates, such as glycerol, lactate, or glycogenic amino acids [28]. In rotifers, the resting eggs contain large amounts of noncarbohydrate substrates as obligatory sources for vital anabolic processes during dormancy and hatching via glyoxylate cycle and gluconeogenesis [10]. The bdelloids are extremely resistant to starvation, which has been shown to extend their lifespan [31], suggesting that the enzymatic machinery required for endogenous de novo glucose production may play a crucial role in their metabolism. On this basis, their observed survival in the presence of an aggregated peptide suggests its partial catabolism.

In order to assess the toxicity of the examined aggregated molecules, the same treatment agents were tested on differentiated SH-SY5Y neuroblastoma cell cultures $[7,26]$. The $\alpha$-Syn and PrPSc, similar to the known toxic $A \beta s$, caused significant reduction of viability, in correlation with their aggregation state (CR affinity). Our in vitro results (Fig. 2) were in line with our a priori expectations and the academic literature $[45,56]$.

The catabolic capability of $P$. acuticornis was not limited to $A \beta 1-42$ (Fig. 3). In the absence of any other potential dietary source, the presence of other neurodegeneration-related aggregates, such as natural (Fig. 3b) or artificial (Fig. 3c) A $\beta$ s; $\alpha-S y n$, PrPC, or PrPSc (Fig. 3d) likewise prolonged the survival of the treated animals compared to the untreated (unfed) controls, except for A $325-35$, which resulted in reduced survival. The median survival showed association with the aggregation state. These results together led us to the conclusion that this extraordinary catabolic activity is universal as regards almost any type of peptide and protein aggregates. In their natural habitat, bdelloids constantly have to cope with extreme fluctuations in nutrient availability [4]. Furthermore, their native food source includes particulate organic detritus, dead bacteria, algae, and protozoa, which offer a large variety of natural 


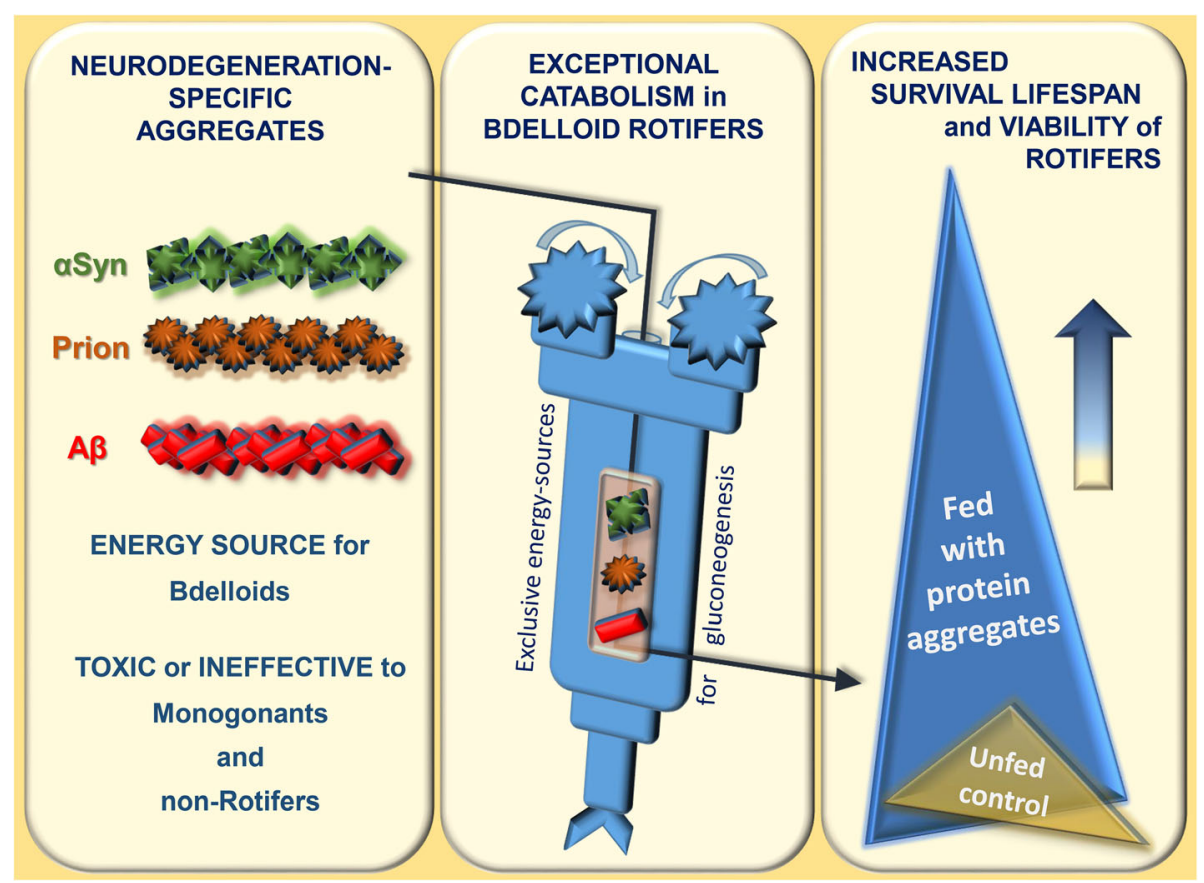

Fig. 5 The general capability of bdelloid rotifers to catabolise neurotoxic aggregates. Neurodegeneration-related peptide and protein aggregates can be utilized as nutrients when given as the only potential energy source for starved bdelloid rotifer species. These agents proved to be either toxic or ineffective for monogonant and non-rotifer species. A currently unidentified mechanism in bdelloid rotifers is hypothesized to enable the utilization of amino acids derived from the degraded aggregates for gluconeogenesis. Compared to the unfed (starved) controls, the bdelloid rotifers treated with aggregates ('fed') demonstrate increased survival and viability

aggregates [50]. Therefore, the capability of these animals to metabolize almost every type of aggregated peptides and proteins might be an evolutionary strategy for adaption and survival.

Our aim was to describe the existence of the in vivo catabolism of neurodegeneration-related aggregates by bdelloid rotifers. The results strongly indicate that these animals can use these toxic agents as an exclusive dietary source to live and grown in an hermetically isolated environment. The available literature does not describe any other metazoan species with a similar capability. In species widely applied in the animal modelling of AD, such as Caenorhabditis elegans, Drosophila melanogaster, Danio rerio, or rodents, the A $\beta 1-42$ are toxic $[11,20,27,41]$. Based on our experiments (Fig. 4), the A $\beta 1-42$ aggregates were also toxic or ineffective to the other microscopic entities tested (monogonant rotifers and non-rotifers). The universal capability of bdelloid rotifers to catabolise peptide and protein aggregates (including such that are known to be neurotoxic) implied that the hypothetic catabolic pathway might consist of degrading enzyme(s), their possible cofactors, and/or anti-aggregation compounds. The comprehensive identification of the molecular background of this unique phenomenon requires further analyses.

\section{Conclusion}

In summary (Fig. 5), we present findings indicating the exceptional capability of the investigated bdelloids to catabolise neurotoxic aggregates in vivo, which is to our knowledge unprecedented in the literature regarding any multicellular animals. In our experimental system, only amino acids could be used for gluconeogenesis by the rotifers; therefore, the aggregates applied represented the only material to be catabolised in the absence of any other food source in this isolated environment. The one-housed $P$. acuticornis individuals maintain their normal phenotypic characteristics and demonstrate significant activity during their life, which require constant energy production. The prolonged lifetime in the presence of (almost all types of) A $\beta s, \alpha$-Syn, PrPC or PrPSc suggests the universal catabolic capability of our model species as regards a wide range of peptide or protein aggregates.

The understanding of the unique catabolic capability of bdelloid rotifers, including $P$. acuticornis, on neurotoxic aggregates in an isolated environment without any other energy source available may provide the basis of a novel therapeutic approach (identification of key molecules and metabolic pathways) in neurodegenerative proteinopathies. 


\section{Abbreviations}

a-Syn: Alpha-synuclein; AD: Alzheimer's disease; Au-AB: Gold-tagged beta-amyloid; AB: Beta-amyloid; BLD: Bright light disturbance; BSA: Bovine serum albumin; BSI: Body size index; CR: Congo red; CRC: Cellular reduction capacity; CSF: Cerebrospinal fluid; DW: Distilled water; EtOH: Ethanol; IDE: Insulin-degrading enzyme; MCF: Mastax contraction frequency; NEP: Neprilysin; NML: Normalized mean lifespan; PD: Parkinson's disease; PrPC: Normal cellular prion protein; PrPSC: Pathogenic prion protein 'scrapie'; SEM: Scanning electron microscope; UC: Untreated control

\section{Acknowledgements}

The authors wish to thank for the contribution of Anna Szentgyorgyi MA (Institute of English and American Studies, University of Szeged, Szeged, Hungary), llona Hatvani, and Prof. Botond Penke. We are grateful to Levente Szalardy MD, PhD (Department of Neurology, University of Szeged) for his valuable contribution in proofreading the manuscript.

\section{Consent of publication}

Not applicable.

\section{Funding}

This research was supported by the GINOP-2.3.2-15-2016-00019 grant to EA and AF.

\section{Availability of data and materials}

The datasets used and/or analysed during the current study available from the corresponding author on reasonable request.

\section{Authors' contributions}

$\mathrm{ZsD}$ was the scientific advisor and together with $\mathrm{ZO}$ and $\mathrm{LM}$ designed and performed the experiments and wrote the manuscript. TH was the medical advisor and contributed with his expertise in neurodegenerative proteinopathies to our experiments. KZs identified the microscopic species. $\mathrm{LF}$ and $\mathrm{ZsB}$ synthesized and prepared the A $\beta$ peptides. BG and ASz helped to analyze the data and carried out the statistical analysis. EA and AF took the SEM photographs. JK coordinated and obtained the resources. All authors approved the final manuscript.

\section{Ethics approval and consent to participate}

All applicable international, national, and/or institutional guidelines for the care and use of animals were followed. Our experiments were performed on microinvertebrates; therefore, according to the current ethical regulations, no specific ethical permission was needed. The investigations were carried out in accordance with globally accepted norms: Animals (Scientific Procedures) Act, 1986, associated guidelines, EU Directive 2010/63/EU for animal experiments and the National Institutes of Health guide for the care and use of Laboratory animals (NIH Publications No. 8023, revised 1978). Our animal studies comply with the ARRIVE guidelines.

\section{Competing interests}

The authors declare that they have no competing interests.

\section{Publisher's Note}

Springer Nature remains neutral with regard to jurisdictional claims in published maps and institutional affiliations.

\section{Author details}

'Department of Psychiatry, Faculty of Medicine, University of Szeged, Kalvaria sgt. 57, Szeged H-6725, Hungary. ${ }^{2}$ MTA-DE Cerebrovascular and Neurodegenerative Research Group, Department of Neuropathology, Institute of Pathology, University of Debrecen, P.O. Box 24, Debrecen H-4012, Hungary. ${ }^{3}$ Department of Old Age Psychiatry, Institute of Psychiatry Psychology \& Neuroscience, King's College London, Box PO70, De Crespigny Park, Denmark Hill, London SE5 8AF, UK. ${ }^{4}$ Agrint Kft., Facan sor 56, Godollo $\mathrm{H}-2100$, Hungary. ${ }^{5}$ Department of Medical Chemistry, Faculty of Medicine, University of Szeged, Semmelweis u. 6, Szeged H-6725, Hungary. ${ }^{6}$ Bioinformatics \& Scientific Computing, Vienna Biocentre Core Facilities, Dr. Bohr-Gasse 3, 1030 Vienna, Austria. ${ }^{7}$ Danube Research Institute, MTA Centre for Ecological Research, Karolina ut 29-31, Budapest H-1113, Hungary. ${ }^{8}$ Sustainable Ecosystems Group, MTA Centre for Ecological Research, Klebelsberg Kuno u. 3, Tihany H-8237, Hungary.
Received: 11 January 2018 Accepted: 11 January 2018

Published online: 29 January 2018

\section{References}

1. Backstrom JR, Lim GP, Cullen MJ, Tökés ZA (1996) Matrix metalloproteinase-9 (MMP-9) is synthesized in neurons of the human hippocampus and is capable of degrading the amyloid-beta peptide (140). J Neurosci 16:7910-7919

2. Baranello RJ, Bharani KL, Padmaraju V, Chopra N, Lahiri DK, Greig NH et al (2015) Amyloid-beta protein clearance and degradation (ABCD) pathways and their role in Alzheimer's disease. Curr Alzheimer Res 12:32-46

3. Bozso Z, Penke B, Simon D, Laczkó I, Juhász G, Szegedi V et al (2010) Controlled in situ preparation of a beta(1-42) oligomers from the isopeptide "iso-a beta(1-42)", physicochemical and biological characterization. Peptides 31:248-256. https://doi.org/10.1016/j.peptides.2009.12.001

4. Castro BB, Antunes SC, Pereira R, Soares AMVM, Gonçalves F (2005) Rotifer community structure in three shallow lakes: seasonal fluctuations and explanatory factors. Hydrobiologia 543:221-232. https://doi.org/10.1007/ s10750-004-7453-8

5. Clément P, Amsellem J, Cornillac AM, Luciani A, Ricci C (1980) An ultrastructural approach to feeding behaviour in Philodina Roseola and Brachionus calycyflorus (rotifers). Hydrobiologia 73:137-141. https://doi.org/ 10.1007/BF00019437

6. Cook DG, Leverenz JB, McMillan PJ, Kulstad JJ, Ericksen S, Roth RA, Schellenberg GD et al (2003) Reduced hippocampal insulin-degrading enzyme in late-onset Alzheimer's disease is associated with the apolipoprotein E-epsilon4 allele. Am J Pathol 162:313-319

7. Datki Z, Juhász A, Gálfi M, Soós K, Papp R, Zádori D et al (2003) Method for measuring neurotoxicity of aggregating polypeptides with the MTT assay on differentiated neuroblastoma cells. Brain Res Bull 62:223-229

8. Datki Z, Papp R, Zádori D, Soós K, Fülöp L, Juhász A et al (2004) In vitro model of neurotoxicity of Abeta 1-42 and neuroprotection by a pentapeptide: irreversible events during the first hour. Neurobiol Dis 17: 507-515. https://doi.org/10.1016/j.nbd.2004.08.007

9. Debortoli N, Li X, Eyres I, Fontaneto D, Hespeels B, Tang CQ et al (2016) Genetic exchange among Bdelloid rotifers is more likely due to horizontal gene transfer than to meiotic sex. Curr Biol 26:723-732. https://doi.org/10. 1016/j.cub.2016.01.031

10. Denekamp NY, Thorne MA, Clark MS, Kube M, Reinhardt R, Lubzens E (2009) Discovering genes associated with dormancy in the monogonant rotifer Brachionus Plicatilis. BMC Genomics 10:108. https://doi.org/10.1186/14712164-10-108

11. Donnini S, Solito R, Cetti E, Corti F, Giachetti A, Carra S et al (2010) Abeta peptides accelerate the senescence of endothelial cells in vitro and in vivo, impairing angiogenesis. FASEB J 24:2385-2395. https://doi.org/10. 1096/fj.09-146456

12. Eckman EA, Reed DK, Eckman CB (2001) Degradation of the Alzheimer's amyloid beta peptide by endothelin-converting enzyme. J Biol Chem 276: 24540-24548. https://doi.org/10.1074/jbc.M007579200

13. Harkany T, Abrahám I, Timmerman W, Laskay G, Tóth B, Sasvári M et al (2000) Beta-amyloid neurotoxicity is mediated by a glutamate-triggered excitotoxic cascade in rat nucleus basalis. Eur J Neurosci 12:2735-2745

14. Hemming ML, Selkoe DJ, Farris W (2007) Effects of prolonged angiotensinconverting enzyme inhibitor treatment on amyloid beta-protein metabolism in mouse models of Alzheimer disease. Neurobiol Dis 26:273281. https://doi.org/10.1016/j.nbd.2007.01.004

15. Hochberg R, Litvaitis MK (2000) Functional morphology of the muscles in Philodina sp. (Rotifera: Bdelloidea). Hydrobiologia 432:57-64. https://doi.org/ 10.1023/A:1004003509017

16. Iwata N, Tsubuki S, Takaki Y, Watanabe K, Sekiguchi M, Hosoki E et al (2000) Identification of the major Abeta1-42-degrading catabolic pathway in brain parenchyma: suppression leads to biochemical and pathological deposition. Nat Med 6:143-150. https://doi.org/10.1038/72237

17. Kalweit AN, Yang H, Colitti-Klausnitzer J, Fülöp L, Bozsó Z, Penke B et al (2015) Acute intracerebral treatment with amyloid-beta (1-42) alters the profile of neuronal oscillations that accompany LTP induction and results in impaired LTP in freely behaving rats. Front Behav Neurosci 9:103. https://doi. org/10.3389/fnbeh.2015.00103

18. Kertész K (1894) Budapest és környékének Rotatoria-Faunája. Rózsa Kálmán és Neje Print, Budapest 
19. Klunk WE, Jacob RF, Mason RP (1999) Quantifying amyloid beta-peptide (Abeta) aggregation using the Congo red-Abeta (CR-abeta) spectrophotometric assay. Anal Biochem 266:66-76. https://doi.org/10.1006/abio.1998.2933

20. Kong Y, Li K, Fu T, Wan C, Zhang D, Song H et al (2016) Quercetin ameliorates $A \beta$ toxicity in drosophila AD model by modulating cell cyclerelated protein expression. Oncotarget 7:67716-67731. https://doi.org/10. 18632/oncotarget.11963

21. Koste W (1978) Rotatoria - Die Radertiere Mitteleuropas. Ein Bestimmunsgwerk, begründet von Max Voigt. Überornung Monogononta. Berlin - Stuttgart. p. 285-289. doi:https://doi.org/10.1002/iroh.19800650226

22. Kuo YM, Webster S, Emmerling MR, De Lima N, Roher AE (1998) Irreversible dimerization/tetramerization and post-translational modifications inhibit proteolytic degradation of a beta peptides of Alzheimer's disease. Biochim Biophys Acta 1406:291-298

23. Kurochkin IV, Goto S (1994) Alzheimer's beta-amyloid peptide specifically interacts with and is degraded by insulin degrading enzyme. FEBS Lett 345:33-37

24. Kutikova LA (1970) Kolovratki fauna SSSR. Fauna SSSR, vol. 4. Akademia Nauk Leningrad, pp. 362-367

25. Langer F, Eisele YS, Fritschi SK, Staufenbiel M, Walker LC, Jucker M (2011) Soluble $A \beta$ seeds are potent inducers of cerebral $\beta$-amyloid deposition. J Neurosci 31:14488-14495. https://doi.org/10.1523/JNEUROSCI.3088-11.2011

26. Li J, Liu CN, Wei N, Li XD, Liu YY, Yang R et al (2016) Protective effects of BAY 73-6691, a selective inhibitor of phosphodiesterase 9, on amyloid- $\beta$ peptides-induced oxidative stress in in-vivo and in-vitro models of Alzheimer's disease. Brain Res 1642:327-335. https://doi.org/10.1016/j. brainres.2016.04.011

27. Link CD (2006) C. Elegans models of age-associated neurodegenerative diseases: lessons from transgenic worm models of Alzheimer's disease. Exp Gerontol 41:1007-1013. https://doi.org/10.1016/j.exger.2006.06.059

28. Liu P, Wang Y, Du X, Yao L, Li F, Meng Z (2015) Transcriptome analysis of thermal parthenogenesis of the domesticated silkworm. PLoS One 10: e0135215. https://doi.org/10.1371/journal.pone.0135215

29. Makin S (2016) Pathology: the prion principle. Nature 538:S13-S16. https:// doi.org/10.1038/538S13a

30. Mawuenyega KG, Sigurdson W, Ovod V, Munsell L, Kasten T, Morris JC, Yarasheski KE, Bateman RJ (2010) Decreased clearance of CNS beta-amyloid in Alzheimer's disease. Science 330:1774. https://doi.org/10.1126/science. 1197623

31. Marotta R, Uggetti A, Ricci C, Leasi F, Melone G (2012) Surviving starvation: changes accompanying starvation tolerance in a bdelloid rotifer. J Morphol 273:1-7. https://doi.org/10.1002/jmor.11000

32. Morell $M$, Bravo $R$, Espargaró $A$, Sisquella $X$, Avilés FX, Fernàndez-Busquets $X$ et al (2008) Inclusion bodies: specificity in their aggregation process and amyloid-like structure. Biochim Biophys Acta 1783:1815-1825. https://doi. org/10.1016/j.bbamcr.2008.06.007

33. Nogrady T, Segers H (2002) Rotifera Vol. 6: Asplanchnidae, Gastropodidae, Lindiidae, Microcodidae, Synchaetidae, Trocoshphaeridae and Filinia. In: H.J. Dumont ed: guides to the identification of the microinvertebrates of the continental waters of the world. Leiden. p. 59-79

34. Olah Z, Bush Al, Aleksza D, Galik B, Ivitz E, Macsai L et al (2017) Novel in vivo experimental viability assays with high sensitivity and throughput capacity using a bdelloid rotifer. Ecotoxicol Environ Saf 144:115-122. https://doi.org/ 10.1016/j.ecoenv.2017.06.005

35. Peelaerts W, Bousset L, Van der Perren A, Moskalyuk A, Pulizzi R, Giugliano $M$ et al (2015) a-Synuclein strains cause distinct synucleinopathies after local and systemic administration. Nature 522:340-344. https://doi.org/10.1038/ nature14547

36. Poeggeler B, Durand G, Polidori A, Pappolla MA, Vega-Naredo I, CotoMontes A et al (2005) Mitochondrial medicine: neuroprotection and life extension by the new amphiphilic nitrone LPBNAH acting as a highly potent antioxidant agent. J Neurochem 95:962-973. https://doi.org/10.1111/ j.1471-4159.2005.03425.x

37. Prusiner SB (1991) Molecular biology of prion diseases. Science 252:1515-1522

38. Riek R, Eisenberg DS (2016) The activities of amyloids from a structural perspective. Nature 539:227-235. https://doi.org/10.1038/nature20416

39. Saido T, Leissring MA (2012) Proteolytic degradation of amyloid $\beta$-protein. Cold Spring Harb Perspect Med 2:a006379. https://doi.org/10.1101/ cshperspect.a006379

40. Salahuddin P, Fatima MT, Abdelhameed AS, Nusrat S, Khan RH (2016) Structure of amyloid oligomers and their mechanisms of toxicities: targeting amyloid oligomers using novel therapeutic approaches. Eur J Med Chem 114:41-58. https://doi.org/10.1016/j.ejmech.2016.02.065

41. Sasaguri H, Nilsson P, Hashimoto S, Nagata K, Saito T, De Strooper B et al (2017) APP mouse models for Alzheimer's disease preclinical studies. EMBO J 36:2473-2487. https://doi.org/10.15252/embj.201797397

42. Sharma N, Khurana N, Muthuraman A (2017) Lower vertebrate and invertebrate models of Alzheimer's disease - a review. Eur J Pharmaco S0014-2999:30603-9. https://doi.org/10.1016/j.ejphar.2017.09.017

43. Selkoe DJ, Abraham CR (1986) Isolation of paired helical filaments and amyloid fibers from human brain. Methods Enzymol 134:388-404

44. Snell TW (2014) Rotifers as models for the biology of aging. Int Rev Hydrobiol 99:84-95. https://doi.org/10.1080/07924259.2014.925516

45. Song J, Kim BC, Nguyen DT, Samidurai M, Choi SM (2017) Levodopa (LDOPA) attenuates endoplasmic reticulum stress response and cell death signaling through DRD2 in SH-SY5Y neuronal cells under a-synucleininduced toxicity. Neuroscience 358:336-348. https://doi.org/10.1016/j. neuroscience.2017.06.060

46. Tomita T (2017) Aberrant proteolytic processing and therapeutic strategies in Alzheimer disease. Adv Biol Regul 64:33-38. https://doi.org/10.1016/j.jbior. 2017.01.001

47. Tucker HM, Kihiko M, Caldwell JN, Wright S, Kawarabayashi T, Price D et al (2000) The plasmin system is induced by and degrades amyloid-beta aggregates. J Neurosci 20:3937-3946

48. Varga L (1966) Rotifers I. Hungarian Academy of Sciences, Budapest

49. Vila-Viçosa D, Campos SR, Baptista AM, Machuqueiro M (2012) Reversibility of prion misfolding: insights from constant-pH molecular dynamics simulations. J Phys Chem B 116:8812-8821. https://doi.org/10.1021/jp3034837

50. Wallace RL, Snell TW (2010) Rotifera, Chapter 8 In: Thorp JH and Covich AP (Eds), Ecology and classification of North American freshwater invertebrates Oxford: Elsevier, p 173-235

51. Wang L, Maji SK, Sawaya MR, Eisenberg D, Riek R (2008) Bacterial inclusion bodies contain amyloid-like structure. PLoS Biol 6:e195. https://doi.org/10. 1371/journal.pbio.0060195

52. Wildburger NC, Esparza TJ, LeDuc RD, Fellers RT, Thomas PM, Cairns NJ et al (2017) Diversity of amyloid-beta Proteoforms in the Alzheimer's disease brain. Sci Rep 7:9520. https://doi.org/10.1038/s41598-017-10422-x

53. Wyss-Coray T (2016) Ageing, neurodegeneration and brain rejuvenation. Nature 539:180-186. https://doi.org/10.1038/nature20411

54. Yasojima K, Akiyama H, McGeer EG, McGeer PL (2001) Reduced neprilysin in high plaque areas of Alzheimer brain: a possible relationship to deficient degradation of beta-amyloid peptide. Neurosci Lett 297:97-100

55. Zhao Z, Xiang Z, Haroutunian V, Buxbaum JD, Stetka B, Pasinetti GM (2007) Insulin degrading enzyme activity selectively decreases in the hippocampal formation of cases at high risk to develop Alzheimer's disease. Neurobiol Aging 28:824-830. https://doi.org/10.1016/j.neurobiolaging.2006.05.001

56. Zhao C, Wang X, He L, Zhu D, Wang B, Du W (2014) Influence of goldbipyridyl derivants on aggregation and disaggregation of the prion neuropeptide PrP106-126. Metallomics 6:2117-2125. https://doi.org/10.1039/c4mt00219a

57. Zhou GP, Huang RB (2013) The pH-triggered conversion of the PrP(c) to PrP(sc.) Curr Top Med Chem 13:1152-1163

\section{Submit your next manuscript to BioMed Central and we will help you at every step:}

- We accept pre-submission inquiries

- Our selector tool helps you to find the most relevant journal

- We provide round the clock customer support

- Convenient online submission

- Thorough peer review

- Inclusion in PubMed and all major indexing services

- Maximum visibility for your research

Submit your manuscript at www.biomedcentral.com/submit 